\title{
Karyotypic diversity between allopatric populations of the group Hoplias malabaricus (Characiformes: Erythrinidae): evolutionary and biogeographic considerations
}

\author{
Daniel Rodrigues Blancoํㅜ, Roberto Laridondo Lui ${ }^{1}$, Luiz Antonio Carlos Bertollo ${ }^{1}$, \\ Vladimir Pavan Margarido ${ }^{2}$ and Orlando Moreira Filho ${ }^{1}$
}

Three populations of the group Hoplias malabaricus from the hydrographic basins of the São Francisco, Araguaia/Tocantins and Xingu Rivers in Brazil were analyzed using classic cytogenetic methods (Giemsa staining, C-banding and Ag-NORs) and molecular methods (fluorescent in situ hybridization with 18S rDNA, 5S rDNA and 5SHindIII satellite DNA probes). The chromosome markers allowed the characterization of these populations as belonging to karyomorph $\mathrm{A}$ and the detection of inter-population divergences. These differences likely stem from different evolutionary histories resulting from geographic isolation between populations associated to the dispersive mode of these organisms, reinforcing genetic diversity in the group Hoplias malabaricus.

Três populações do grupo Hoplias malabaricus das bacias hidrográficas dos rios São Francisco, Araguaia/Tocantins e Xingu foram analisadas citogeneticamente utilizando-se métodos clássicos (coloração com Giemsa, bandamento-C e Ag-RONs) e moleculares (hibridização in situ fluorescente com sondas de rDNA 18S, rDNA 5S e DNA satélite 5SHindIII). Os marcadores cromossômicos foram fundamentais para a caracterização destas populações como pertencentes ao cariomorfo A e para detecção de claras divergências interpopulacionais. Estas diferenças são provavelmente oriundas de diferentes histórias evolutivas do isolamento geográfico entre as populações associado ao modo dispersivo destes organismos, reiterando a diversidade genética do grupo Hoplias malabaricus.

Key words: Cytogenetics, Trahira, Karyomorph A, FISH, Geographic isolation.

\section{Introduction}

Erythrinidae is a small family of Neotropical teleost fish, widely distributed throughout South America, currently made up of three genera - Hoplerythrinus, Erythrinus and Hoplias - and an extinct genus - Paleohoplias assisbrasiliensis (Gayet et al., 2003). Hoplias is the most widely spread genus on the South American continent, comprising two large groups: $H$. malabaricus and $H$. lacerdae. In a recent revision, Oyakawa \& Mattox (2009) recognized six species for the latter group: $H$. intermedius, H. aimara, H. curupira, $H$. brasiliensis, $H$. australis and $H$. lacerdae. The group H. malabaricus remains in need of a revision as a whole.

Due to their sedentary habits, Erythrinidae species are not capable of overcoming obstacles such as waterfalls and large rapids, unlike large migratory teleost fish in South
America, such as Salminus brasiliensis, Brycon spp. and large catfish. Thus, such natural obstacles are factors that can reduce the gene flow between populations in the same hydrographic basin, which can even be interrupted, depending on the topography or geomorphology of the region. Hoplias malabaricus is easily found in temporary lakes during the dry season (Okada et al., 2003) due to its higher capacity for survival in environments with a low content of dissolved oxygen and extreme water temperatures in comparison to most other piscivorous teleost fish (Rantin et al., 1992, 1993; Rios et al., 2002). In the rainy season, $H$. malabaricus exhibits a high degree of passive dispersion (not intrinsic to the biology of the teleost fish, but dependent on environmental factors), migrating from one stretch of the river to another through strips of water a few centimeters in depth, which is a common condition in floodplains. Moreover, the fingerlings are

\footnotetext{
${ }^{1}$ Departamento de Genética e Evolução, Universidade Federal de São Carlos. Rodovia Washington Luís (SP 310) Km 235, 13565-905 São Carlos, SP, Brazil.

${ }^{2}$ Centro de Ciências Biológicas e da Saúde, Universidade Estadual do Oeste do Paraná. Rua Universitária 2069, 85814-110 Cascavel, PR, Brazil.
} 
entomophagous and do not require the presence of other teleost fish for feeding, thereby exhibiting high resistance to famine (Azevedo \& Gomes, 1943).

Erythrinidae species display karyotype variation of evolutional interest (Bertollo et al., 2000, 2004; GiulianoCaetano et al., 2001; Diniz \& Bertollo, 2003; Vicari et al., 2005). In this context, H. malabaricus stands out as the most studied group, with cytogenetically sampled populations in different regions of South America - from Argentina to Suriname and, especially, Brazil (Bertollo et al., 2000). The data obtained characterize a conspicuous karyotype diversity, with seven differentiated karyomorphs (A, B, C, D, E, F and G), considering the diploid number, chromosome morphology and sex chromosome system. While some karyomorphs have wide geographic distribution, others are endemic to particular regions and karyomorphs can occur in sympatry without the detection of hybrids, thereby indicating the occurrence of a species complex (Bertollo et al., 2000). Karyomorph A has wide geographic distribution and is found in the main hydrographic basins of Brazil, such as the Paraná, São Francisco, Araguaia, Amazon Rivers as well as basins in the eastern portion of the country. Smaller karyotype variations between populations of this karyomorph have also been detected (Born \& Bertollo, 2001; Vicari et al., 2005; Cioffi et al., 2009).

The aim of the present study was to employ classical and molecular cytogenetic methods in order to characterize three allopatric populations of the group H. malabaricus pertaining to three different hydrographic basins: the São Francisco, Araguaia/Tocantins and Xingu Rivers. The results obtained contributed to the understanding of the evolutionary biology of $H$. malabaricus, particularly with regard to the diversification and conservation of chromosome markers of interest in this group.

\section{Material and Methods}

Eighty-seven specimens from the group Hoplias malabaricus were cytogenetically analyzed: 14 males and 9 females from the Tropeiros Lagoon (São Francisco River basin - transposition region from the Piumhi River in the State of Minas Gerais); 16 males and 20 females from bank lagoons of the Araguaia River (Araguaia/Tocantins River basin in the State of Goiás); and 16 males and 12 females from the tributaries of the Sete de Setembro River (Xingu River basin in the State of Mato Grosso). The teleost fish were anesthetized with clove oil, based on the method described by Henyey et al. (2002). The mitotic chromosomes were obtained from the cells of the anterior portion of the kidney (Bertollo et al., 1978; Foresti et al., 1993) and classified as metacentric (m) and submetacentric (sm), based on the arm ratio (Levan et al., 1964). C-positive heterochromatin was evidenced using the method described by Sumner (1972), with some adaptations (Lui et al., 2009), and the nucleolus organizer regions (NORs) were determined based on the method described by Howell \& Black (1980). Both methods were administered sequentially, following the conventional staining of the chromosomes with Giemsa.
Fluorescent in situ hybridization (FISH) was performed based on the method described by Pinkel et al. (1986), with some modifications, using the 18S rDNA (Cioffi et al., 2009), 5S rDNA and 5SHindIII satellite DNA probes (Martins et al., 2006). The probes were tagged with biotin-14-dATP by nick translation, following the manufacture's instructions (Bionick Labeling System - Invitrogen). The chromosomes were incubated in RNase $(0.4 \% \mathrm{RNase} / 2 \mathrm{xSSC})$ for one hour at $37^{\circ} \mathrm{C}$ in a wet chamber. After denaturation carried out with $70 \%$ formamide in $2 \mathrm{xSSC}$ at $70^{\circ} \mathrm{C}$ for four minutes, the slides were dehydrated in $50 \%$ and $100 \%$ ethanol series for five minutes each. Probe was dissolved at a concentration of $3 \mathrm{ng} / \mu \mathrm{l}$ in the hybridization mixture (50\% formamide, $2 \mathrm{xSSC}, 10 \%$ dextran sulfate). Hybridization was carried out in a wet chamber at $37^{\circ} \mathrm{C}$ for approximately 16 hours. The slides were then washed twice in $2 \mathrm{xSSC}$ at $37^{\circ} \mathrm{C}$ for six minutes each and subsequently incubated in $1 \times$ PBD $(200 \mathrm{~mL}$ of $20 x S S C, 6 \mathrm{~mL}$ of Triton 100 , $10 \mathrm{~g}$ of non-fat powdered milk, $800 \mathrm{~mL}$ of distilled water). The detection of the signal was performed with $3.5 \mu \mathrm{L}$ of FITC (1:100 dilution - Sigma) and $27 \mu \mathrm{L}$ of $\mathrm{C}$ buffer $\left(0.1 \mathrm{M}\right.$ of $\mathrm{NaHCO}_{3}$ and $0.15 \mathrm{M}$ of $\mathrm{NaCl}, \mathrm{pH} 8.5$ ) per slide for 30 minutes at $37^{\circ} \mathrm{C}$ in a wet chamber. Following three washes with $1 \mathrm{xPBD}$ at $45^{\circ} \mathrm{C}$ for four minutes each, three rounds of signal amplification were carried out using $40 \mu \mathrm{l}$ of anti-avidin-biotin solution ( $95 \% 1 \times$ PBD, $5 \%$ anti-avidin) per slide for 20 minutes at $37^{\circ} \mathrm{C}$. After three washes with $1 \times \mathrm{PBD}$ at $45^{\circ} \mathrm{C}$ for four minutes, each slide was treated with $3.5 \mu \mathrm{L}$ of FITC $(1: 100)+27 \mu \mathrm{L}$ of $\mathrm{C}$ buffer for 20 minutes at $37^{\circ} \mathrm{C}$ in a wet chamber. After the final washes, the chromosomes were counterstained with $0.7 \mu \mathrm{L}$ propidium iodide $(50 \mu \mathrm{g} / \mathrm{ml})+20 \mu \mathrm{L}$ of antifading per slide and analyzed under an epifluorescence microscope (Olympus BX50). Imaging was obtained with the Image-Pro Plus version 6.3 (Media Cybernetics) program.

\section{Results}

\section{Hoplias malabaricus from the São Francisco River basin}

The specimens from this population had $2 \mathrm{n}=42$ chromosomes $(22 \mathrm{~m}+20 \mathrm{sm})$ and Fundamental Number $(\mathrm{FN})=$ 84 in both males and females, with no chromosome heteromorphism related to sex. C-banding revealed pericentromeric bands in the majority of chromosomes; some chromosomes also exhibited terminal and interstitial bands. Submetacentric pair 17 clearly stood out, with a large band in the terminal region of the long arm, which were co-localized with the Ag-NORs (Fig. 1a, b, c). Fluorescent in situ hybridization (FISH) with the 5S rDNA probe revealed two chromosome pairs with interstitial sites: one small metacentric pair (n 10) with sites in the long arm and one large submetacentric pair (n 13) with sites in the short arm near the centromere (Fig. 2a). 18S rDNA sites were found in four chromosome pairs: two metacentric pairs (n 6 and 9) with sites located in the terminal region of both chromosome arms and two submetacentric pairs (n 16 and 17) with sites in the long arms in the region near the centromere and the terminal region, respectively (Fig. 2b). FISH with the 5SHindIII satellite DNA 
probe identified nine chromosome pairs with sites in the centromeric region: three metacentric pairs (n 1,5 and 6) and six submetacentric pairs (n 12, 13, 14, 18, 19 and 21) (Fig. 2c).

\section{Hoplias malabaricus from the Araguaia River basin}

The specimens collected in São Miguel do Araguaia had $2 \mathrm{n}=42$ chromosomes $(18 \mathrm{~m}+24 \mathrm{sm})$ and $\mathrm{FN}=84$ in both males and females, with no chromosome heteromorphism related to sex. Heterochromatin was found distributed in the pericentromeric and terminal region in several chromosomes of the complement. Submetacentric pair 10 clearly stood out, with a large band in the pericentromeric region; pairs 14 and 20 had conspicuous bands in the terminal region of the long arm, which were co-localized with the Ag-NORs (Fig. 1d, e, f). FISH with the 5S rDNA probe revealed only one small metacentric pair (n 8) labeled in the interstitial region of the long arms (Fig. 2d). 18S rDNA sites were labeled in three pairs of submetacentric chromosomes: one large pair (n 10) in the region near the centromere and two smaller pairs (n 14 and 20) in the terminal region of the long arms. Moreover, only one of the homologues of pair 10 had an extra site, which was in the terminal region of the long arm (Fig. 2e). FISH with the 5SHindIII satellite DNA probe identified eight chromosome pairs with sites in the centromeric region: two metacentric pairs (n 1 and 5) and six submetacentic pairs (n 10, 11, 12, 15, 16 and 21) (Fig. 2f). a
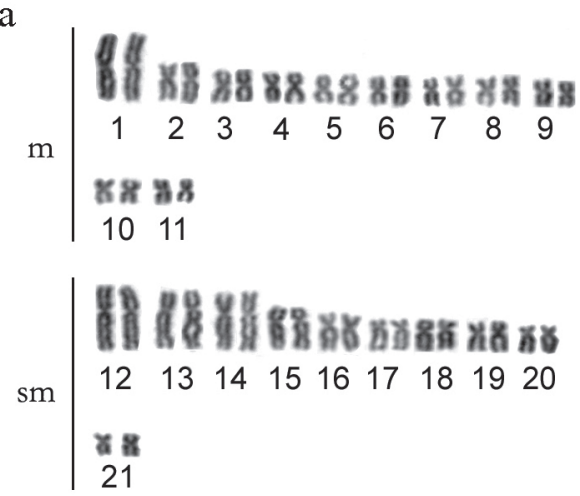

d

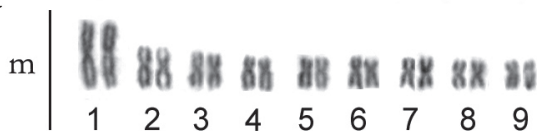

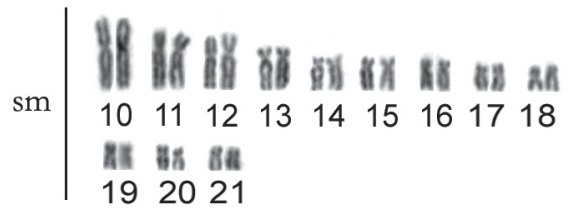

g
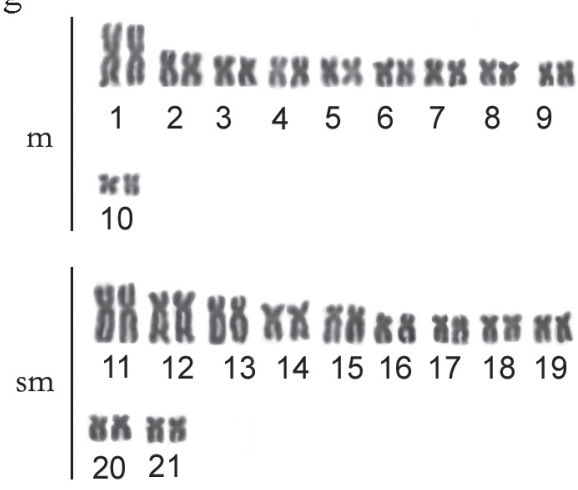

b
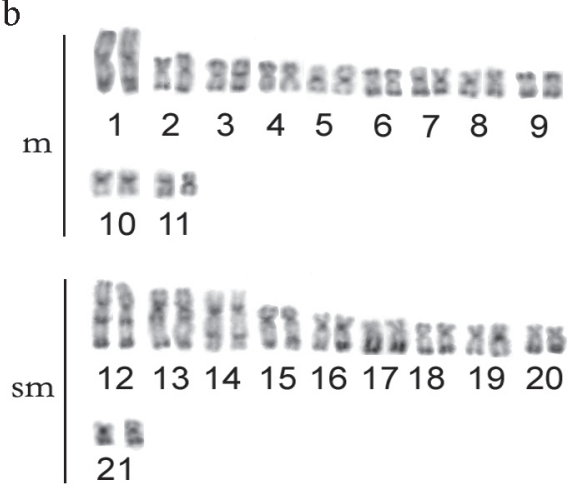

e

$\mathrm{m}$

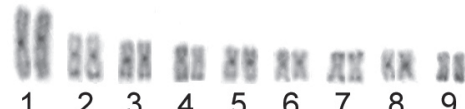

f
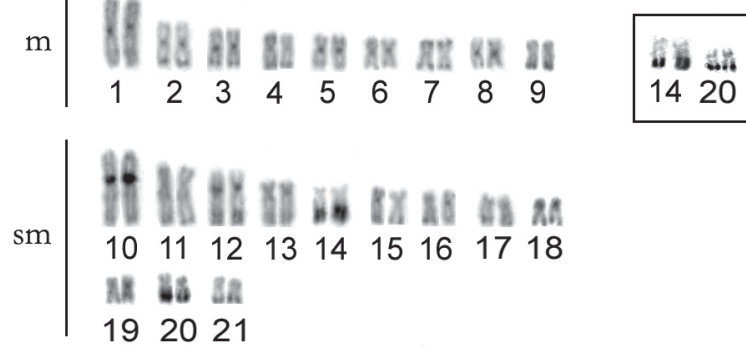

h
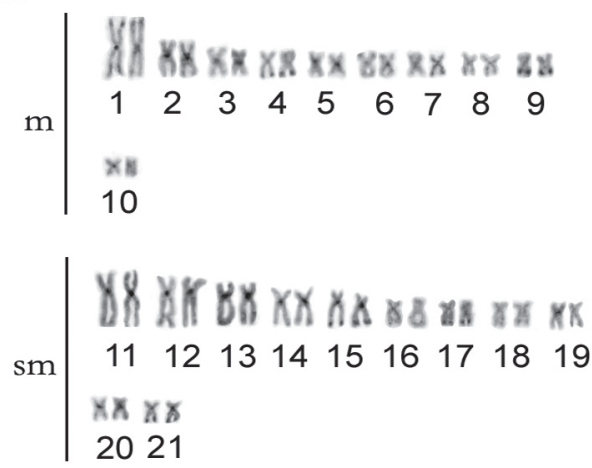

$\mathrm{c}$

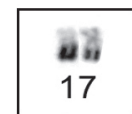




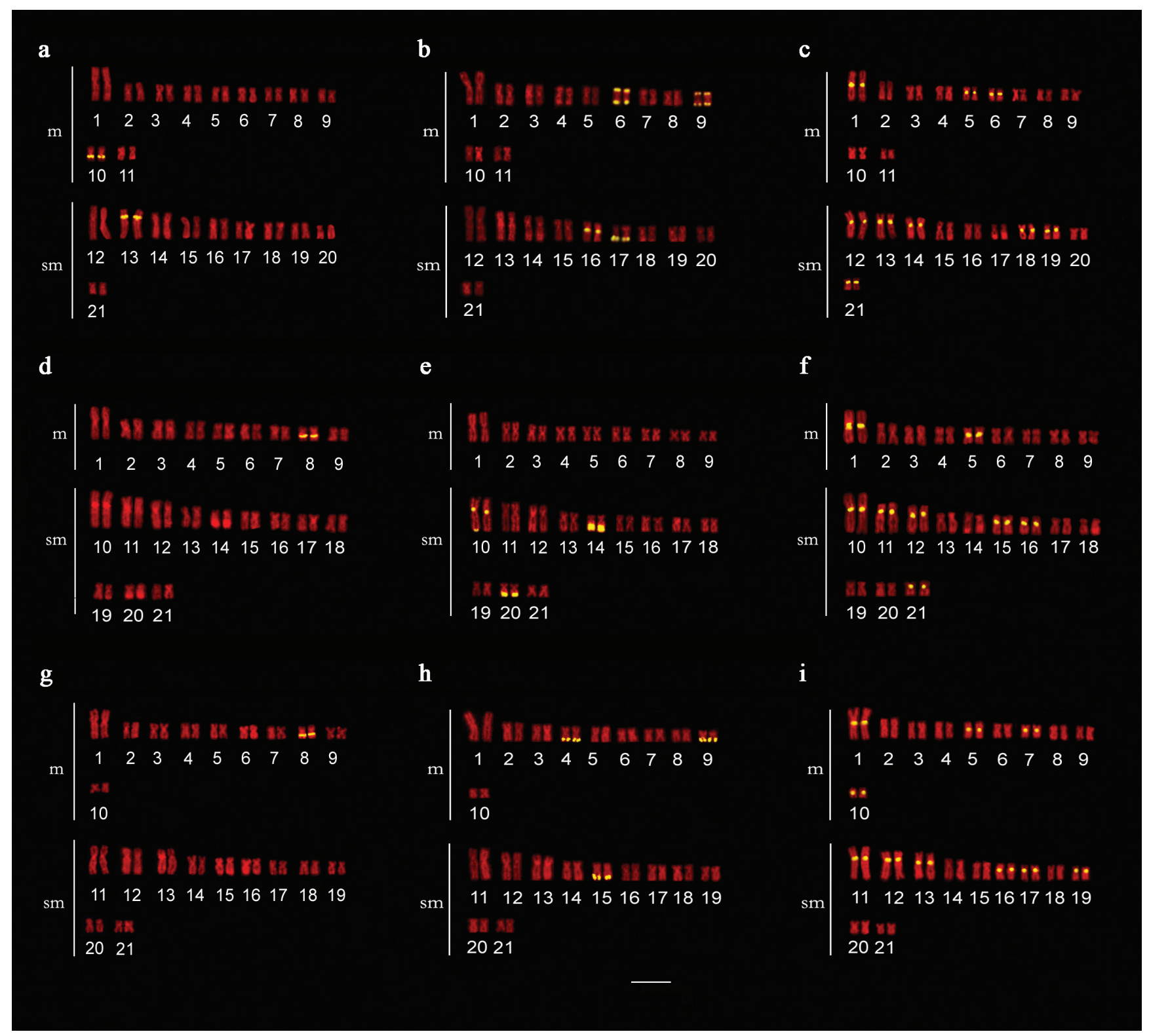

Fig. 2. Hoplias malabaricus karyotypes (karyomorph A) with fluorescent in situ hybridization (FISH) using 5S rDNA(a, d, g), $18 \mathrm{~S}$ rDNA $(\mathbf{b}, \mathbf{e}, \mathbf{h})$ and $5 \mathrm{SHind}$ III satellite DNA $(\mathbf{c}, \mathbf{f}, \mathbf{i})$ probes in the populations from the basins of the São Francisco $(\mathbf{a}, \mathbf{b}, \mathbf{c})$, Araguaia (d, e, f) and Xingu (g, h, i) Rivers. Scale bar $=5 \mu \mathrm{m}$.

\section{Hoplias malabaricus from the basin of the Xingu River}

The specimens collected from the tributaries of the Sete de Setembro River had $2 n=42$ chromosomes $(20 m+22 \mathrm{sm})$ and $\mathrm{FN}=84$ for both males and females, with no heteromorphic sex chromosome system. C-banding revealed pericentromeric bands in nearly all the chromosomes as well as small terminal bands on some pairs. Silver nitrate staining revealed three chromosome pairs (n 4, 9 and 15) with Ag-NORs (Fig. 1g, h, i). FISH with the $5 \mathrm{~S}$ rDNA probe revealed only one metacentric pair (n 8) labeled in the interstitial region of the long arms (Fig. 2g). 18S rDNA sites were labeled in the terminal region of the long arms in three pairs of chromosomes: two metacentric pairs (n 4 and 9) and one submetacentric pair (n 15) (Fig. 2h). FISH with the 5SHindIII satellite DNA probe identified 10 chromosome pairs with sites in the centromeric region: four metacentric pairs (n 1, 5, 7 and 10) and six submetacentric pairs (n 11, 12, 13, 16, 17 and 19) (Fig. 2i).

\section{Discussion}

The three populations studied had $2 n=42$ chromosomes in both males and females, with no heteromorphic sex chromosomes, thereby characterizing karyomorph A(Bertollo et al., 2000). Although they had the same diploid number and fundamental number $(\mathrm{FN}=84)$, the karyotype formulae of the three populations revealed subtle differences in the number of metacentric and submetacentric chromosomes (Figs. 1 and 3). Variations in karyotype formula are commonly found among 
karyomorph A populations of the group H. malabaricus (Table 1) and are likely related to the occurrence of Robertsonian rearrangements - more specifically, pericentric inversions (Galetti et al., 1994), which may be fixed due to the isolation of small local populations (allopatric evolution). However, considering the general structure of the karyotype, there was greater similarity between the populations of the São Francisco basin and Xingu River, which were more clearly differentiated from the population of the Araguaia River, which showed an in increase in the number of submetacentric chromosomes in relation to the metacentric chromosomes (Figs. 1 and 3).

Pericentromeric and terminal heterochromatic bands have frequently been found in the group H. malabaricus (Dergam \& Bertollo, 1990; Haaf et al., 1993; Bertollo et al., 1997 a, b; Born \& Bertollo, 2000; Vicari et al., 2005; Blanco et al., 2009), as also seen in the populations of the present study. However, some degree of variation in the amount and location of heterochromatin were also evident. Thus, the population from the São Francisco River basin had characteristic interstitial bands in the long arm of the three pairs of submetacentric chromosomes, which were either absent or not as evident in the other populations. Only the population of the Araguaia River basin had three heterochromatic blocks in submetacentric chromosome pairs 10, 14 and 20, which represent a large portion of the amount of heterochromatin in the karyotype (Figs. 1 and 3). A general comparative analysis of the amount and distribution of heterochromatin revealed once again a greater similarity between the populations from the basins of the Xingu and São Francisco Rivers, whereas the population from the Araguaia River differed in the considerably lower amount of heterochromatin (Figs. 1 and 3).

a

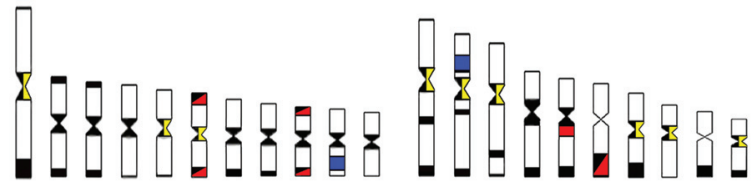

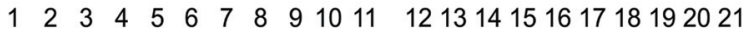

b

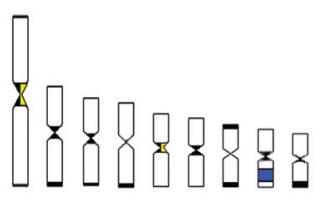

$\begin{array}{lllllllll}1 & 2 & 3 & 4 & 5 & 6 & 7 & 8 & 9\end{array}$

C

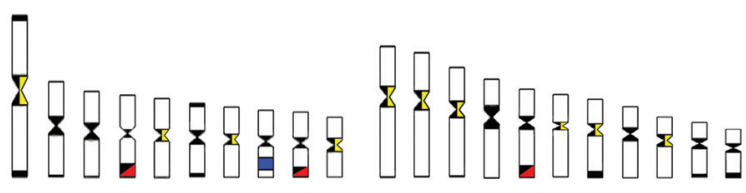

$1 \quad 2 \quad 3 \quad 4 \quad 5 \quad 6 \quad 7 \quad 8 \quad 910 \quad 1112131415161718192021$

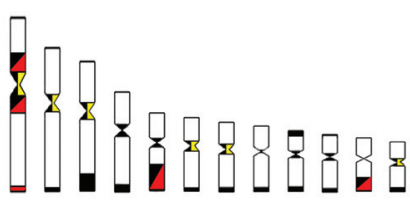

101112131415161718192021
Fig. 3. Ideograms referring to the Hoplias malabaricus populations (karyomorph A) from the São Francisco (a), Araguaia (b) and Xingu (c) Rivers, highlighting the chromosome markers. Black $=\mathrm{C}$-positive heterochromatin; blue $=5 \mathrm{~S}$ rDNA sites; red $=18 \mathrm{~S}$ rDNA sites; yellow $=5$ SHindIII satellite DNA sites.
The three populations proved conserved with regard to the number and location of 5S rDNA, with a single site in the interstitial region of the long arm of one small metacentric chromosome pair (Figs. 2 and 3). However, the population from the São Francisco River exhibited an extra site in the proximal region of the short arm of one large submetacentric chromosome pair (pair 13). Although this proximal 5S rDNA site has not been observed in the majority of populations of H. malabaricus analyzed thus far, it is likely to be a plesiomorphic condition, once this similar character state has been observed in other species of the genus Hoplias, such as $H$. intermedius (cited as $H$. aff. lacerdae) and in some karyomorphs/populations of $H$. malabaricus (Ferreira et al., 2007; Blanco et al., 2010).

The repetitive DNA family 5 SHindIII, with localization in the centromeric region in H. malabaricus, is exclusive to this group among the Erythrinidae and it was present in the ancestral of the different karyomorphs (Ferreira et al., 2007). Variation was found for this marker in the number of sites among the populations studied, which may be related to the unstable nature and high evolutionary rate of repetitive sequences (Charlesworth et al., 1994). Despite, some chromosomes demonstrated an evident correspondence with regard to this sequence. The first and fifth metacentric pair as well as the three first submetacentric pairs consistently presented 5SHindIII sites in the three populations. Three smaller submetacentric chromosome pairs were also labeled in all the populations - some with correspondence between them (pairs 18, 19 and 21 for the São Francisco River basin; pairs 15, 16 and 21 for the Araguaia River basin; pairs 16, 17 and 19 for the Xingu River basin). Thus, the analysis of the distribution of this family of repetitive DNA proved to be important to the understanding of karyotype evolution in $H$. malabaricus, revealing conserved chromosome pairs alongside others that were divergent with regard to these sequences and indicating that nature of the differentiation had occurred among these populations.

The occurrence of multiple telomeric NORs is another common characteristic in the group H. malabaricus, although interstitial NORs may also occur with lesser frequency (Bertollo, 1996; Born \& Bertollo, 2001, 2006; Vicari et al., 2005). The populations from the basins of the São Francisco and Araguaia Rivers had both terminal and interstitial ribosomal sites, whereas the population from the Xingu River basin only had terminal bands. In the majority of populations in this group studied thus far, there has been no occurrence of interstitial sites of active NORs (Ag-NORs), as these are generally restricted to terminal sites in $H$. malabaricus group. This was observed for the population from the São Francisco River basin as well as that from the Araguaia River basin (Fig. 1). Heterochromatic segments intercalated with or adjacent to ribosomal sites are frequent among Neotropical teleost fish, as seen in the three populations studied, which apparently enables the dispersion of NOR sites throughout the genome (Vicari et al., 2008). There is a remarkable similarity among submetacentric chromosome pairs 17, 14 and 15, which 
Table 1. Review of the cytogenetic studies of different populations of karyomorph A of the Hoplias malabaricus.

\begin{tabular}{|c|c|c|}
\hline Locality & Karyotypic formula & References \\
\hline Manaus (AM) - Igarapé Mindu & $24 m+18 s m$ & Bertollo et al. (2000), Born \& Bertollo (2001) \\
\hline Poconé (MT) - Bento Gomes River & - & Bertollo et al. (2000) \\
\hline Araguaiana (MT) - Dois de Agosto Stream & $20 m+22 s m$ & Bertollo et al. (2000), Born \& Bertollo (2001) \\
\hline São Miguel do Araguaia (GO) - Medo Stream & $18 m+24 s m$ & Present study \\
\hline Três Marias (MG) - São Francisco River & - & Bertollo et al. (2000) \\
\hline Ecological Reserve of Jataí (SP) - Mogi-Guaçu River & - & Scavone et al. (1994) \\
\hline S. J. do Marinheiro (SP) - Água Vermelha: Grande River & - & Bertollo et al. (2000) \\
\hline Conceição das Alagoas (MG) - Volta Grande Reservoir & - & Dergan (1996) \\
\hline Represa de Furnas (MG) - Grande River & $22 m+20 s m$ & Blanco et al. (2009) \\
\hline Capitólio (MG) - Piumhi River & $22 \mathrm{~m}+20 \mathrm{sm}$ & Blanco et al. (2009), Present study \\
\hline Juquiá (SP) - Juquiá River & - & Bertollo et al. (2000) \\
\hline Itatinga Avaré (SP) - Jurumirim Reservoir: Paranapanema River & $24 m+18 s m$ & Bertollo et al. (2000), Born \& Bertollo (2001) \\
\hline Descalvado (SP) - Pântano River & $22 m+20 s m$ & Cioffi et al. (2009) \\
\hline Palmeiras (PR) - Iguaçu River & $24 m+18 s m$ & Vicari et al. $(2003,2005,2006)$ \\
\hline Poço Preto (SC) - Iguaçu River & - & Bertollo et al. (2000) \\
\hline Guaíba (RS) - Guaíba River & - & Bertollo et al. (2000) \\
\hline Canarana (MT) - Sete de Setembro River & $20 m+22 s m$ & Present study \\
\hline Santo Antônio do Legever (MT) - Cuiabá River & $22 m+20 s m$ & Cioffi et al. (2009) \\
\hline Corrientes - Argentina - Aguapey River & - & Lopes \& Fenocchio (1994), Lopes et al. (1998) \\
\hline Tacuarembó - Uruguai - Negro River & - & Dergam (unpublished data) \\
\hline Ponta Grossa (PR) - Tibagi River & $24 m+18 s m$ & Vicari et al. (2005) \\
\hline Ivaí (PR) - Ivaí River & $24 m+18 s m$ & Vicari et al. (2005) \\
\hline Castro (PR) - Ribeira River & $24 m+18 s m$ & Vicari et al. (2005) \\
\hline Pariquera-Açu (SP) - Ribeira River & $24 m+18 s m$ & Vicari et al. (2005) \\
\hline Rio Grande (RS) - Bolaxa Stream & $22 \mathrm{~m}+20 \mathrm{sm}$ & Born \& Bertollo (2001) \\
\hline São Carlos (SP) Guaporé Farm & $20 m+22 s m$ & Born \& Bertollo (2001) \\
\hline Passos (MG) - Grande River & $22 m+20 s m$ & Born \& Bertollo (2001) \\
\hline Porto Rico (PR) - upper Paraná River & $24 m+18 s m$ & Pazza \& Júlio Jr (2003) \\
\hline Nova Prata do Iguaçu (PR) - Iguaçu River & $24 m+18 s m$ & Vicari et al. (2006) \\
\hline Botucatu (SP) - Aquará River & - & Martins et al. (2006), Ferreira et al. (2007) \\
\hline Parque Florestal do Rio Doce (MG) - Rio Doce Lagoons & $22 \mathrm{~m}+20 \mathrm{sm}$ & Born \& Bertollo (2006), Cioffi et al. (2009) \\
\hline Piraquara (PR) - Canquiri Farm, Iguaçu River & $20 \mathrm{~m}+22 \mathrm{sm}$ & Lemos et al. (2002) \\
\hline
\end{tabular}

have $18 \mathrm{~S}$ rDNA sequences, among the populations from the São Francisco, Araguaia and Xingu Rivers respectively, indicating a likely homology among the karyotypes (Fig. 3). Such relationships suggest that despite the existent interpopulation divergences, some sites remain conserved, possibly due to some particular role that they exert. The presence of one NOR site in only one of the homologues of pair 10 in the population from the Araguaia River basin (Fig. 2) may be due to an accentuated size heteromorphism. Indeed, heteromorphism in NOR size, possibly stemming from unequal crossing over, is commonly found in Neotropical teleost fish, which may eventually reduce the size of one of the homologous sites drastically, making it undetectable with standard FISH methods.

Bitelomeric NORs (those that are present in both telomeric regions in a single chromosome) are a recurring characteristic in the different H. malabaricus karyomorphs (Bertollo, 1996; Vicari et al., 2005; Blanco et al., 2009; Cioffi et al., 2009) as well as in some other species of teleost fish, such as Pyrrhulina cf. australis (Oliveira et al., 1991), Poecilia latipunctata (Galetti Jr. \& Rash, 1993) and Astyanax scabripinnis (Mantovani et al., 2005). There has been no record thus far of any population belonging to karyomorph A of $H$. malabaricus that does not exhibit bitelomeric NORs, as evidenced in the populations from the basins of the Xingu and Araguaia Rivers (Fig. 2). However, there is a remarkable correspondence between metacentric chromosome pairs 4 and 9 in the population from the Xingu River basin and pairs 6 and 9 in the population from the São Francisco River basin, although the latter exhibits bitelomeric NORs (Fig. 3).

The Brazilian fossil from the Mio-Pliocene ('Paleohoplias assisbrasiliensis) belonging to the family Erythrinidae demonstrates how old this group of Neotropical teleost fish is (Gayet et al., 2003), existing for at least five million years. This observation, together with a host of other important characteristics of $H$. malabaricus, such as (a) broad geographic distribution in the hydrographic basins of South America (Bertollo et al., 2000), (b) the formation of isolated populations in the same hydrographic basin due to geological events (formation of waterfalls, large rapids or lakes), (c) 
ecological characteristics favorable to dispersion (survival under adverse conditions) and (d) easy adaptation to new environments (physiological and predation characteristics) (Azevedo \& Gomes, 1943; Rantin et al., 1992, 1993; Rios et al., 2002), may explain the considerable karyotype diversity in this group of teleost fish. Such divergence likely stems from different evolutionary histories resulting from population isolation, such that the H. malabaricus karyomorphs may be distinct biological units. The chromosome markers (classic and molecular) used in the present study proved adequate for the identification of biodiversity among different populations of karyomorph A of $H$. malabaricus, corroborating data obtained from other markers in other populations of this same karyomorph (Born \& Bertollo, 2001; Vicari et al., 2005).

\section{Acknowledgements}

The authors are grateful to Osvaldo T. Oyakawa (MZUSP) for the identification of the specimens; to Pedro L. Gallo and Luis H. da Silva (Piau) for help with the sampling; to the Instituto Brasileiro do Meio Ambiente e dos Recursos Naturais Renováveis (IBAMA - License number: 10538-1) and the Instituto Estadual de Florestas (IEF/MG) for authorization to collect the material; and to Marcelo R. Vicari (UEPG) for his suggestions and ideas. This study was financed by the Fundação de Amparo à Pesquisa do Estado de São Paulo (FAPESP) and the Conselho Nacional de Desenvolvimento Científico e Tecnológico (CNPq).

\section{Literature Cited}

Azevedo, P. \& A. L. Gomes. 1943. Contribuição ao estudo da biologia da Traíra Hoplias malabaricus (Bloch, 1794). Boletim de Indústria Animal, 5(4): 15-64.

Bertollo, L. A. C. 1996. The nucleolar organizer regions of Erythrinidae fish. An uncommon situation in the genus Hoplias. Cytologia, 61: 75-81.

Bertollo, L. A. C., G. G. Born, J. A. Dergam, A. S. Fenocchio \& O. Moreira-Filho. 2000. A biodiversity approach in the Neotropical Erythrinidae fish, Hoplias malabaricus. Karyotypic survey, geographic distribution of cytotypes and cytotaxonomic considerations. Chromosome Research, 8: 603-613.

Bertollo, L. A. C., M. S. Fontes, A. S. Fenocchio \& J. Cano. 1997a. The $\mathrm{X}_{1} \mathrm{X}_{2} \mathrm{Y}$ sex chromosome system in the fish Hoplias malabaricus. I. G-, C- and chromosome replication banding. Chromosome Research, 5: 493-499.

Bertollo, L. A. C., O. Moreira-Filho \& M. S. Fontes. 1997 b. Karyotypic diversity and distribution in Hoplias malabaricus (Pisces, Erythrinidae): cytotypes with $2 \mathrm{n}=40$ chromosomes. Brazilian Journal of Genetics, 20: 237-242.

Bertollo, L. A. C., C. Oliveira, W. F. Molina, V. P. Margarido, M. S. Fontes, M. C. Pastori, J. N. Falcão \& A. S. Fenocchio. 2004. Chromosome evolution in the erythrinid fish, Erythrinus erythrinus (Teleostei: Characiformes). Heredity, 93: 228-233.

Bertollo, L. A. C., C. S. Takahashi \& O. Moreira-Filho. 1978. Cytotaxonomic considerations on Hoplias lacerdae (Pisces, Erythrinidae). Brazilian Journal of Genetics, 1: 103-120.
Blanco, D. R., R. L. Lui, L. A. C. Bertollo, D. Diniz \& O. MoreiraFilho. 2010. Characterization of invasive fish species in a river transposition region: evolutionary chromosome studies in the genus Hoplias (Characiformes, Erythrinidae). Reviews in Fish Biology and Fisheries, 20: 1-8.

Born, G. G. \& L. A. C. Bertollo. 2000. An XX/XY sex chromosome system in a fish species, Hoplias malabaricus, with a polymorphic NOR-bearing X chromosome. Chromosome Research, 8: 111-118.

Born, G. G. \& L. A. C. Bertollo. 2001. Comparative cytogenetics among allopatric populations of the fish, Hoplias malabaricus. Cytotypes with $2 \mathrm{n}=42$ chromosomes. Genetica, 110: 1-9.

Born, G. G. \& L. A. C. Bertollo. 2006. A new sympatric region for distinct karyotypic forms of Hoplias malabaricus (Pisces, Erythrinidae). Brazilian Journal of Biology, 66: 205-210.

Charlesworth, B., P. Snlegowski \& W. Stephan. 1994. The evolutionary dynamics of repetitive DNA in eukaryotes. Nature, 371:215-220.

Cioffi, M. B., C. Martins, L. Centofante, U. Jacobina \& L. A. C. Bertollo. 2009. Chromosomal variability among allopatric populations of Erythrinidae fish Hoplias malabaricus: mapping of three classes of repetitive DNAs. Cytogenetic and Genome Research, 125: 132-141.

Dergam, J. A. 1996. Phylogeography and character congruence within the Hoplias malabaricus Block, 1794 (Erythrinidae, Characiformes, Ostariophysi) species complex. Unpublished Ph.D. thesis. Colorado State University, USA.

Dergam, J. A. \& L. A. C. Bertollo. 1990. Karyotypic diversification in Hoplias malabaricus (Osteichthyes, Erythrinidae) of São Francisco and Alto Paraná basins, Brazil. Brazilian Journal of Genetics, 13: 755-766.

Diniz, D. \& L. A. C. Bertollo. 2003. Karyotypic studies on Hoplerythrinus unitaeniatus (Pisces, Erythrinidae) populations. A biodiversity analysis. Caryologia, 56: 303-313.

Ferreira, I. A., L. A. C. Bertollo \& C. Martins. 2007. Comparative chromosome mapping of 5S rDNA and 5SHindIII repetitive sequences in Erythrinidae fishes (Characiformes) with emphasis on the Hoplias malabaricus 'species complex'. Cytogenetic and Genome Research, 118: 78-83.

Foresti, F., C. Oliveira \& L. F. Almeida-Toledo. 1993. A method for chromosome preparations from large fish specimens using in vitro short-term treatment with colchicines. Experientia, 49: 810-813.

Galetti Jr, P. M., L. A. C. Bertollo \& O. Moreira-Filho. 1994. Trends in chromosome evolution of neotropical characiform fishes. Caryologia, 47(3-4): 289-297.

Galetti Jr, P. M. \& E. M. Rash. 1993. NOR variability in diploid and triploid forms at the Amazon molly Poecilia formosa as show by silver nitrate and chromomycin A3 staining. Brazilian Journal of Genetics, 16: 927-938.

Gayet, M., M. Jégu, J. Bocquentin \& F. R. Negri. 2003. New characoids from the upper Cretaceous and Paleocene of Bolivia and the Mio-Pliocene of Brazil: phylogenetic position and paleobiogeographic implications. Journal of Vertebrate Paleontology, 23: 28-46.

Giuliano-Caetano, L., L. C. Jorge, O. Moreira-Filho \& L. A. C Bertollo. 2001. Comparative cytogenetic studies on Hoplerythrinus unitaeniatus populations (Pisces, Erythrinidae). Cytologia, 66: 39-43.

Haaf, T., M. Schmid, C. Steinlein, P. M. Galetti Jr \& H. F. Willard. 1993. Organization and molecular cytogenetics of satellite DNA family from Hoplias malabaricus (Pisces, Erythrinidae). Chromosome Research, 1: 77-86. 
Henyey, E., B. Kynard \& P. Zhuang. 2002. Use of electronarcosis to immobilize juvenile lake and shortnose sturgeons for handling and the effects on their behavior. Journal of Applied Ichthyology, 18: 502-504.

Howell, W. M. \& D. A. Black. 1980. Controlled silver staining of nucleolus organizer regions with a protective colloidal developer: a 1-step method. Experientia, 36: 1014-1015.

Lemos, P. M. M., A. S. Fenocchio, L. A. C. Bertollo \& M. M. Cestari. 2002. Karyotypic studies on two Hoplias malabaricus (Characiformes, Erythrinidae) of the $2 n=42$ group, from the first plateau of the Iguaçu river basin (Paraná State, Brazil). Caryologia, 55(3): 193-198.

Levan, A., K. Fredga \& A. A. Sandberg. 1964. Nomenclature for centromeric position on chromosomes. Hereditas, 52: 201-220.

Lopes, P. A., A. J. Alberdi, J. A. Dergam \& A. S. Fenocchio. 1998. Cytotaxonomy of Hoplias malabaricus (Osteichthyes, Erythrinidae) in the Aguapey river (Province of Corrientes, Argentina). Copeia, 1998: 485-487.

Lopes, P. A. \& A. S. Fenocchio. 1994. Confirmation of two different cytotypes for the neotropical fish Hoplias malabaricus Gill 1903 (Characiformes). Cytobios, 80: 217-221.

Lui, R. L., D. R. Blanco, V. P. Margarido \& O. Moreira-Filho. 2009. First description of B chromosomes in the family Auchenipteridae, Parauchenipterus galeatus (Siluriformes) of the São Francisco River basin (MG, Brazil). Micron, 40(5-6): 552-559.

Mantovani, M., L. D. S. Abel \& O. Moreira-Filho. 2005. Conserved $5 \mathrm{~S}$ and variable $45 \mathrm{~S}$ rDNA chromosomal localization revealed by FISH in Astyanax scabripinnis (Pisces, Characidae). Genetica, 123: 211-216.

Martins, C., I. A. Ferreira, C. Oliveira, F. Foresti \& P. M. Galetti Jr. 2006. A tandemly repetitive centromeric DNA sequence of the fish Hoplias malabaricus (Characiformes: Erythrinidae) is derived from 5S rDNA. Genetica, 127: 133-141.

Okada, E. K., A. A. Agostinho, M. Petrere Jr. \& T. Penczak. 2003. Factors affecting fish diversity and abundance in drying ponds and lagoons in the upper Paraná River basin, Brazil. Ecohydrology and Hydrobiology, 3(1): 97-110.

Oliveira, C., A. A. Andreata, L. F. Almeida-Toledo \& S. A. ToledoFilho. 1991. Karyotype and nucleolus organizer regions Pyrrhulina cf. australis (Pisces, Characiformes, Lebiasinidae). Brazilian Journal of Genetics, 14: 685-690.

Oyakawa, O. T. \& G. M. T. Mattox. 2009. Revision of the Neotropical trahiras of the Hoplias lacerdae species-group (Ostariophysi: Characiformes: Erythrinidae) with descriptions of two new species. Neotropical Ichthyology, 7(2): 117-140.
Pazza, R. \& H. F. Julio Jr. 2003. Occurrence of three sympatric cytotypes of Hoplias malabaricus (Pisces, Erythrinidae) in the upper Paraná river foodplain (Brazil). Cytologia, 68(2): 159-163.

Pinkel, D., T. Straume \& J. Gray. 1986. Cytogenetic analysis using quantitative, high-sensitivity, fluorescence hybridization. Proceedings of the National Academy of Sciences, 83: 2934-2938.

Rantin, F. T., M. L. Glass, A. L. Kalinin, R. M. M. Verzola \& M. N. Fernandes. 1993. Cardio-respiratory responses in two ecologically distinct erythrinids (Hoplias malabaricus and Hoplias lacerdae) exposed to graded environmental hypoxia. Environmental Biology of Fishes, 36: 93-97.

Rantin, F. T., A. L. Kalinin, M. L. Glass \& M. N. Fernandes. 1992. Respiratory responses to hypoxia in relation to mode of life of two erythrinid species (Hoplias malabaricus and Hoplias lacerdae). Journal of Fish Biology, 41: 805-812.

Rios, F. S., A. L. Kalinin \& F. T. Rantin. 2002. The effects of longterm food deprivation on respiration and hematology of the neotropical fish Hoplias malabaricus. Journal of Fish Biology, 61: 85-95.

Scavone, M. D. P., L. A. C. Bertollo \& M. M. Cavallini. 1994. Sympatric occurrence of two Karyotypic forms of Hoplias malabaricus (Pisces, Erythrinidae). Cytobios, 80: 223-227.

Sumner, A. T. 1972. A simple technique for demonstrating centromeric heterochromatin. Experimental Cell Research, 75: 304-306.

Vicari, M. R., R. F. Artoni \& L. A. C. Bertollo. 2003. Heterochromatin polymorphism associated with 18S rDNA: a differential pathway among Hoplias malabaricus fish populations. Cytogenetic and Genome Research, 101: 24-28.

Vicari, M. R., R. F. Artoni \& L. A. C. Bertollo. 2005. Comparative cytogenetics of Hoplias malabaricus (Pisces, Erythrinidae): A population analysis in adjacent hydrographic basins. Genetics and Molecular Biology, 28: 103-110.

Vicari, M. R., R. F. Artoni, O. Moreira-Filho \& L. A. C. Bertollo. 2008. Colocalization of repetitive DNAs and silencing of major rRNA genes. A case report of the fish Astyanax janeiroensis. Cytogenetic and Genome Research, 122: 67-72.

Vicari, M. R., R. Pazza, R. F. Artoni, V. P. Margarido \& L. A. C. Bertollo. 2006. Cytogenetics and biogeography: considerations about the natural origin of Hoplias malabaricus (Characiformes, Erythrinidae) on the Iguaçu River. Brazilian Archives of Biology and Technology, 49(2): 297-303. 